O $\quad$ R I I G I N A I

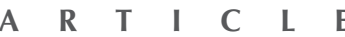

X Wang 王 瀟 LP Leung 梁令邦

\title{
Clinical profile of patients with undiagnosed human immunodeficiency virus infection presenting to a local emergency department: a pilot study
}

\begin{abstract}
Objectives To investigate the clinical profile of patients unaware of having human immunodeficiency virus (HIV) infection on presentation to the emergency department and provide a direction for future prospective studies on undiagnosed HIV infection in emergency department patients.

Design Retrospective, descriptive case series.

Setting A university teaching hospital in Hong Kong.

Patients Patients who were diagnosed for the first time with HIV infection or acquired immunodeficiency syndrome after presenting to the accident and emergency department from 2001 to 2011.

Main outcome measures Demographic and clinical characteristics of the recruited patients.

Results Forty-four patients satisfied the inclusion criteria and were analysed. Most patients (36\%) were 40 to 49 years old. Heterosexual practice was admitted by $73 \%$ of them. Fever $(48 \%)$ was the commonest presenting symptom. Ten patients died during their index admission. There were no significant differences between those who died and survivors with regard to gender, age, triage category, and CD4 cell counts. Nor were there any significant differences in gender, age distribution, and sexual orientation in these patients compared with the sample used in surveillance studies by the Centre for Health Protection in Hong Kong.

Conclusion Patients unaware of HIV infection are not commonly encountered in accident and emergency department settings. Targeted screening of males aged between 20 and 49 years may increase the yield of HIV testing in such settings.
\end{abstract}

Key words

Delayed diagnosis; Emergency medical services; HIV infections; Population surveillance

Hong Kong Med J 2013;19:300-4 DOI: $10.12809 / \mathrm{hkmj} 133902$

Accident and Emergency Department, Queen Mary Hospital, Pokfulam, Hong Kong X Wang, MB, B

LP Leung, FHKAM (Emergency Medicine)

Correspondence to: Dr LP Leung Email: leunglp@ha.org.hk

\section{Introduction}

Human immunodeficiency virus (HIV) infection has become a global epidemic since its emergence 3 decades ago. Globally, 34 million persons were living with HIV in 2009, of whom 4.9 million were in Asia. ${ }^{1}$ According to the Centre for Health Protection (CHP) of Hong Kong, in 2011, there were 520 new cases of HIV infection and the estimated prevalence of HIV infection in the local population was $<0.1 \% .^{2}$ Specifically, respective prevalence rates were $<0.01 \%, 0.02 \%, 0.15 \%$, and $0.48 \%$ among blood donors, expectant mothers attending the antenatal clinics, social hygiene clinic attendees, and methadone clinic attendees. ${ }^{3}$ However, these figures probably underestimate the true situation. This is because in Hong Kong, many still consider HIV infection and its behavioural risk factors a social stigma. Infected persons may not come to medical attention easily. At present, the major source of reported HIV infection is from the public health care sector. However, there 
has been no study of HIV prevalence among those presenting to accident and emergency departments (AEDs). Annual attendances at local AEDs exceed 2 million. If the mean prevalence of HIV is $0.1 \%, 2000$ HIV-infected persons may have attended the AEDs in a year. Identifying these infected persons not only allows earlier medical intervention (which is shown to be beneficial), ${ }^{4}$ but also reduces its spread and benefits the public as a whole. In a US study, it was estimated that a quarter of HIV-infected persons who were not aware of the infection were responsible for 54 to $70 \%$ of new cases. ${ }^{5}$

To make early identification of infected persons possible, a screening programme is required. Different organisations or countries have different recommendations on such screening. The World Health Organization recommends routine screening if there is a generalised HIV epidemic. For places with a low-level epidemic, screening is suggested for patients at antenatal, tuberculosis, and sexual health clinics. ${ }^{6}$ The United States Centers for Disease Control and Prevention recommends HIV testing of all persons aged 13 to 64 years in all health care settings, if the prevalence is $0.1 \%$ or higher. ${ }^{7}$ In the United Kingdom, there is a similar recommendation if the prevalence exceeds $0.2 \% .^{8}$ In a recently published emergency department-based study, non-targeted screening was claimed to be useful in finding patients with unrecognised infection. ${ }^{9}$ In Hong Kong, there are two universal testing programmes, which target: (1) drug users attending the methadone clinics, and (2) expectant mothers attending antenatal services. ${ }^{3}$ In other health care settings, including AEDs, to test or not is clinically based; there being no formal recommendation. Currently, the prevalence of HIV infection among AED patients is unknown. The value and feasibility of HIV screening for AED patients are also unknown. Owing to the large volume of patients using AED services, studies relating to this issue may be worthwhile. This pilot study therefore aimed at investigating the clinical profile of patients who were unaware of HIV infection on presentation to the AED. Its purpose was to obtain preliminary data and provide a direction for future prospective studies on issues relating to undiagnosed HIV infections among AED patients.

\section{Methods}

This pilot study entailed a retrospective design. A prospective study into this issue was expected to meet with difficulties. First, the acceptability of HIV testing by AED patients and staff is unknown. Second, hitherto, the prevalence of HIV infection among local AED patients has never been estimated. Third, it was also unclear whether the findings contained in reports from the CHP were applicable in the AED population. Thus, it was difficult to calculate the

\section{到急症室求診的未確診人類免疫缺陷病毒威染的 患者的臨床觀察：先導研究}

目的探討到急症室求診的未確診人類免疫缺陷病毒感染 ( HIV ) 患者的臨床觀察, 並為將來提供一個具前瞻 性的研究方向。

設計 回顧及描述性病例系列。

安排 香港一所大學的教學醫院。

患者 2001 至 2011 年期間在急症室求診後才首次發現有HIV 感染或愛滋病病毒感染的患者。

主要結果測量 患者的人口學和臨床特徵。

結果 分析了 44 名符合研究納入標準的患者。大多數患者 (36\%) 介乎40至49歲，當中 $73 \%$ 自稱為異性戀者。 發熱是病人最常見的症狀 $(48 \%)$ 。患者中 10 例於首 次求診期間死亡。死者和倖存者於性別、年齡、分流 類別及CD4細胞數量方面並無顯著差異。與香港衛生 防護中心監測研究中的患者相比, 本研究的病人在性 別、年齡分佈和性取向方面沒有任何明顯差異。

結論 向急症室求診而不曉得自己受HIV感染的人並不普 遍。在急症室內為年齡介乎 20 至 49 歲的男性進行HIV 病毒檢測可能更有效地進行篩選。

appropriate sample size to conduct a prospective study. The primary disadvantage of a retrospective design is that it cannot provide the prevalence of HIV infection, though it may provide a 'snap-shot' of the situation.

Subjects were included if they were admitted through the AED of Queen Mary Hospital, Hong Kong and discharged with a principal diagnosis of HIV infection or AIDS (ICD-10 codes: B20.8, B21.8, B23.1, B23.2, B23.8, B24, R75, Z21) from 1 January 2001 to 31 December 2011; and the diagnosis was made for the first time during the index AED presentation and linked admission. Subjects were searched for in the Clinical Data Analysis and Reporting System of the Hospital Authority. As many subjects as eligible were recruited. Clinical records of eligible subjects were obtained from the Clinical Management System. Information retrieved included demographic characteristics (age, gender, ethnicity, source of referral, occupation, and sexual orientation) and clinical characteristics. The latter included a history of sexually transmitted disease (STD), including nonmarital venereal exposure (VE) and intravenous (IV) drug use, the AED-presenting complaints, triage category, CD4 cell counts at the index admission, time between symptom onset and AED consultation, and mortality. All information relating to the identity of a recruited subject was delinked from the data collected for analysis. This study was approved by 
the institutional review board of the Hong Kong West Cluster of the Hospital Authority / The University of Hong Kong.

\section{Statistical analysis}

Descriptive statistics were used to describe the demographic and clinical variables. For testing significance, Mann-Whitney $U$ tests were used for continuous variables and Chi squared tests for categorical variables. A comparison of this sample with the cumulative sample (1984-September 2011) from the HIV surveillance programme by the CHP was undertaken to ascertain any similarity in terms of demographic characteristics, for which the 2sample $t$ test with equal variance was used. For all significance tests, any $\mathrm{P}<0.05$ was considered statistically significant.

\section{Results}

During the study period, there were 1.36 million attendances to the AED with 0.43 million admissions. In all, 105 patients admitted via the AED had a discharged diagnosis of HIV infection. Only 44 were diagnosed with HIV infection for the first time during their admission for the index AED presentation; 61 patients were excluded from the analysis because they were known to be HIV carriers or infected persons before the index presentation.

The mean age of these 44 patients was 41 years; over $80 \%$ were younger than 50 years. The majority were males $(77 \%)$, most being ethnic Chinese or South-East Asians. Self-referral was most common; 10 $(23 \%)$ were referred by the Stanley prison hospital. Their occupations varied; domestic helpers and service workers (bank tellers, waiters, etc) accounted for a quarter of them. Ten were prisoners. As for their sexual orientation, most were heterosexual (Table 1).

As for their clinical characteristics (Table 2), most did not have a history of STD, VE, or IV drug use. Fever was the most common presenting symptom. Most presented within 1 month of symptom onset. Over half of them belonged to triage category III (considered potentially unstable). The mean CD4 cell counts on admission was 54 cells/ $\mu \mathrm{L}$. Ten patients died during their index admission, over half of whom were clinically unstable on presentation (Table 3 ).

When compared with the CHP sample, apart from ethnicity, there were no significant differences in terms of gender, age distribution, and sexual orientation between the groups (Table 4).

\section{Discussion}

The number of AED patients with undiagnosed HIV infection as revealed in this pilot study was small.
TABLE I. Demographic characteristics

\begin{tabular}{|c|c|}
\hline Characteristic & No. $(\%)$ of patients* \\
\hline \multicolumn{2}{|l|}{ Age (years) } \\
\hline Mean \pm standard deviation & $41 \pm 12$ \\
\hline Range & $22-75$ \\
\hline \multicolumn{2}{|l|}{ Gender vs age distribution (years) } \\
\hline Male & $34(77)$ \\
\hline $20-29$ & $6(14)$ \\
\hline $30-39$ & $9(20)$ \\
\hline $40-49$ & $12(27)$ \\
\hline$\geq 50$ & 7 (16) \\
\hline Female & $10(23)$ \\
\hline $20-29$ & $4(9)$ \\
\hline $30-39$ & $2(5)$ \\
\hline $40-49$ & $4(9)$ \\
\hline$\geq 50$ & $0(0)$ \\
\hline \multicolumn{2}{|l|}{ Ethnicity } \\
\hline Chinese & $17(39)$ \\
\hline \multicolumn{2}{|l|}{ Non-Chinese } \\
\hline Vietnamese & $9(20)$ \\
\hline Filipino & $5(11)$ \\
\hline Indonesian & $3(7)$ \\
\hline Thai & $3(7)$ \\
\hline Indian & $2(5)$ \\
\hline Nepalese & $1(2)$ \\
\hline Malaysian & $1(2)$ \\
\hline German & $1(2)$ \\
\hline Austrian & $1(2)$ \\
\hline British & $1(2)$ \\
\hline \multicolumn{2}{|l|}{ Source of referral } \\
\hline Self & $24(55)$ \\
\hline Stanley prison hospital & $10(23)$ \\
\hline Private hospital or clinic & $9(20)$ \\
\hline Public out-patient clinic & $1(2)$ \\
\hline \multicolumn{2}{|l|}{ Occupation $^{\dagger}$} \\
\hline Prisoners & $10(23)$ \\
\hline Domestic helpers & $7(16)$ \\
\hline Managers and administrators & $3(7)$ \\
\hline \multicolumn{2}{|l|}{ Professionals } \\
\hline Financial sector & $3(7)$ \\
\hline Teacher & $1(2)$ \\
\hline Surveyor & $1(2)$ \\
\hline Accountant & $1(2)$ \\
\hline Engineer & $1(2)$ \\
\hline Associated professionals & $1(2)$ \\
\hline Clerks & $2(5)$ \\
\hline Service workers & $5(11)$ \\
\hline Elementary occupations & $4(9)$ \\
\hline Fishery workers & $1(2)$ \\
\hline Unclassified & $4(9)$ \\
\hline \multicolumn{2}{|l|}{ Sexual orientation } \\
\hline Homosexual & $12(27)$ \\
\hline Heterosexual & $32(73)$ \\
\hline
\end{tabular}

Unless otherwise indicated

International Standard Classification of Occupations (ISCO-08) 
TABLE 2. Clinical characteristics

\begin{tabular}{|c|c|}
\hline Characteristic & No. $(\%)$ of patients* \\
\hline \multicolumn{2}{|l|}{ History of sexually transmitted disease } \\
\hline Yes & $2(5)$ \\
\hline No & $42(95)$ \\
\hline \multicolumn{2}{|l|}{ History of venereal exposure } \\
\hline Yes & $10(23)$ \\
\hline No & $34(77)$ \\
\hline \multicolumn{2}{|l|}{ History of intravenous drug use } \\
\hline Yes & $8(18)$ \\
\hline No & $36(82)$ \\
\hline \multicolumn{2}{|l|}{ Presenting complaints $^{\dagger}$} \\
\hline \multicolumn{2}{|l|}{ Constitutional symptoms } \\
\hline Fever & $21(48)$ \\
\hline Weight loss & $19(43)$ \\
\hline \multicolumn{2}{|l|}{ Neurological symptoms } \\
\hline Confusion & $2(5)$ \\
\hline Syncope & $2(5)$ \\
\hline Headache & $1(2)$ \\
\hline Amnesia & $1(2)$ \\
\hline Facial nerve palsy & $1(2)$ \\
\hline Dizziness & $1(2)$ \\
\hline Hemiparesis & $1(2)$ \\
\hline \multicolumn{2}{|l|}{ Respiratory symptoms } \\
\hline Cough & $9(20)$ \\
\hline Dyspnoea & $8(18)$ \\
\hline \multicolumn{2}{|l|}{ Gastro-intestinal symptoms } \\
\hline Diarrhoea & $4(9)$ \\
\hline \multicolumn{2}{|l|}{ Others } \\
\hline Oral candidiasis & $3(7)$ \\
\hline \multicolumn{2}{|l|}{ Triage category ${ }^{\ddagger}$} \\
\hline I & $0(0)$ \\
\hline II & $3(7)$ \\
\hline III & $24(55)$ \\
\hline IV & $14(32)$ \\
\hline $\mathrm{V}$ & $1(2)$ \\
\hline Not available & $2(5)$ \\
\hline \multicolumn{2}{|l|}{ CD4 cell counts on admission } \\
\hline Mean \pm standard deviation (cells $/ \mu \mathrm{L}$ ) & $54 \pm 81$ \\
\hline \multicolumn{2}{|l|}{$\begin{array}{l}\text { Time between symptom onset and } \\
\text { accident \& emergency consultation }\end{array}$} \\
\hline$<1$ Week & $13(30)$ \\
\hline$<1$ Month & $21(48)$ \\
\hline$<6$ Months & $8(18)$ \\
\hline$>6$ Months & $2(5)$ \\
\hline Mortality & $10(23)$ \\
\hline
\end{tabular}

* Unless otherwise indicated

Some patients had more than one type of presenting symptoms

Category I: life-threatening condition with unstable vital signs

Category II: potentially life-threatening condition with borderline vital signs

Category III: condition with stable vital signs but with potential risk of rapid deterioration

Category IV: condition with stable vital signs and no immediate risk of deterioration

Category V: minor condition with no risk of complication
TABLE 3. Comparison between deceased and survivors

\begin{tabular}{lccc}
\hline Characteristic & $\begin{array}{c}\text { Deceased } \\
(\mathbf{n}=\mathbf{1 0})\end{array}$ & $\begin{array}{c}\text { Survived } \\
(\mathbf{n}=\mathbf{3 4})\end{array}$ & P value \\
\hline Male & $90 \%$ & $74 \%$ & 0.20 \\
Mean age (years) & 43 & 40 & 0.50 \\
CD4 cell counts (cells/ML) & 41 & 57 & 0.51 \\
Triage category I to III & $60 \%$ & $28 \%$ & 0.05 \\
\hline
\end{tabular}

Although this retrospective study cannot provide an accurate estimate of the prevalence of undiagnosed HIV infection among such patients, judging from total attendances during the study period and the estimation of prevalence made by the CHP, it seems that undiagnosed HIV infection in them is uncommon.

As for their demographic characteristics, the majority of patients were young, heterosexual males. Apart from ethnicity, there was no significant difference between them and the CHP sample with respect to age, gender, and sexual orientation. The fact that in this study over $60 \%$ of the patients were non-Chinese (in contrast to about $30 \%$ in the CHP sample) is probably explained by the AED being their first contact point for health care in Hong Kong. However, as 61 patients with known HIV infection were excluded from analysis, the issue of ethnicity needs further exploration. Of the 44 patients analysed in this study, $10(23 \%)$ were prisoners and seven were domestic helpers. A high percentage of prisoners is not an unexpected finding. For instance, in Canada, HIV prevalence among their federal offenders is more than 10 times that of the general population. ${ }^{10}$ For the seven domestic helpers, all were females of South-East Asian in ethnicity, and made up $70 \%$ (7/10) of all the female patients and $16 \%$ of the entire sample. Pre-employment HIV testing for foreign domestic helpers is a common practice in Hong Kong. Theoretically, all foreign domestic helpers working here should have been tested negative. This study's findings suggest that if clinically indicated, repeat testing may sometimes be necessary.

Most patients in this sample did not report a history of STD, VE, or IV drug use. Apart from potential recall bias inherent in a retrospective design, it may reflect a different spectrum of patients seen in AEDs and is an issue that warrants further investigation. As for clinical presentations, HIV infection is characterised by an acute seroconversion illness followed by the development of chronic or opportunistic infections. At any stage of the disease, fever is common and was also the most common presenting feature in this study. Most of the patients presented at an advanced stage of the illness. This was reflected by the low CD4 cell counts present in $62 \%$ of the patients that were clinically unstable at triage, 
TABLE 4. Comparison with the Centre for Health Protection (CHP) sample

\begin{tabular}{lccc}
\hline Characteristics & $\begin{array}{c}\text { Study sample } \\
\text { (2001-2011) }\end{array}$ & $\begin{array}{c}\text { CHP cumulative sample } \\
\text { (1984-September 2011) }\end{array}$ & P value \\
\hline Male gender & $77 \%$ & $80 \%$ & 0.95 \\
Chinese & $39 \%$ & $66 \%$ & $<0.001$ \\
Homosexual & $27 \%$ & $27 \%$ & 0.99 \\
Mean age (years) & 41 & 38 & 0.2 \\
Peak age range (years) & $30-49(61 \%)$ & $30-49(58 \%)$ & 0.89 \\
\hline
\end{tabular}

and was compatible with observations in a previous local study. ${ }^{11}$ The $23 \%$ mortality rate during the index admission was relatively high and consistent with the observation that these patients often present with advanced disease. Notably, $60 \%$ of those who died were in triage category I to III.

Despite being limited by its retrospective design and execution in a single institution, this study nevertheless yielded useful conclusions. It showed that only a small number of HIV-infected patients were unaware of their status at presentation to the AED, suggesting that this setting is probably not suitable for non-targeted HIV screening. However, no firm recommendation can be made, unless the true prevalence of HIV infection is known. A prospective, territory-wide study involving a large number of AED patients is needed to resolve this issue. As most local AEDs are overwhelmed by heavy patient loads, a study of such a scale is likely to meet resistance. Be that as it may, in this study most of the patients were males aged 20 to 49 years. According to Hospital Authority statistics of AED attendance, the gender distribution of AED attendees is approximately equal and most patients are older than 50 years. ${ }^{12}$ It might therefore be reasonable to propose targeted HIV screening on males aged between 20 and 49 years not aware of their HIV status. This would greatly enhance the feasibility of such a programme by limiting the numbers. Moreover, HIV testing should be considered particularly for detainees of correctional service facilities and the foreign domestic helpers who attend the AED.

\section{Conclusion}

This pilot study has provided a 'snap-shot' of the demographics and clinical characteristics of patients unaware of HIV infection who present to AEDs. Nontargeted HIV screening in the AED setting is probably inappropriate. Targeted screening of males aged between 20 and 49 years may increase the yield of positive HIV tests in the AED setting.

\section{References}

1. UNAIDS report on the global AIDS epidemic 2010. Epidemic update. Geneva, Switzerland: UNAIDS; 2010.

2. Centre for Health Protection, Department of Health, Hong Kong. Hong Kong STD/AIDS update. Quarter 3, 2011:17.

3. Centre for Health Protection, Department of Health, Hong Kong. HIV surveillance report 2010 update; 2011.

4. Strategies for Management of Antiretroviral Therapy (SMART) Study Group, Emery S, Neuhaus JA, et al. Major clinical outcomes in antiretroviral therapy (ART)—naive participants and in those not receiving ART at baseline in the SMART study. J Infect Dis 2008;197:1133-44. cross ref

5. Marks G, Crepaz N, Janssen RS. Estimating sexual transmission of HIV from persons aware and unaware that they are infected with the virus in the USA. AIDS 2006;20:1447-50. cross ref

6. World Health Organization. Guidance on providerinitiated HIV testing and counselling in health facilities. 2007. Available from: http://www.who.int/hiv/pub/ guidelines/9789241595568_en.pdf. Accessed 29 Apr 2012.

7. Branson BM, Handsfield HH, Lampe MA, et al. Revised recommendations for HIV testing of adults, adolescents and pregnant women in healthcare settings. MMWR Recomm Rep 2006;55(RR-44):1-17.

8. British HIV Association, British Association of Sexual Health and HIV, British Infection Society. UK National Guidelines for HIV testing 2008. London: BHIVA; 2008: 10.

9. Haukoos JS, Hopkins E, Conroy AA, et al. Routine opt-out rapid HIV screening and detection of HIV infection in emergency department patients. JAMA 2010;304:28492. cross ref

10. Correctional Service of Canada. Infectious diseases prevention and control in Canadian federal penitentiaries, 2000-1, 2010. Available from: http://www.csc-scc. gc.ca/text/pblct/infdscfp-2007-08/index-eng.shtml\#_ Toc315419527. Accessed 14 May 2012.

11. Wong KH, Lee SS, Low KH, Wan WY. Temporal trend and factors associated with late HIV diagnosis in Hong Kong, a low prevalence locality. AIDS Patient Care STDS 2003;17:461-9. cross ref

12. Hospital Authority Statistical Report (2011-2012). Statistics and Workforce Planning Department, Hospital Authority; Jun 2013. 